\title{
What and how advanced medical students learn from reasoning through multiple cases
}

Citation for published version (APA):

Boshuizen, E., van de Wiel, M. W. J., \& Schmidt, H. (2012). What and how advanced medical students learn from reasoning through multiple cases. Instructional Science, 40(5), 755-768. https://doi.org/10.1007/s11251012-9211-z

\section{DOI:}

10.1007/s11251-012-9211-z

Document status and date:

Published: 01/09/2012

Document Version:

Other version

Please check the document version of this publication:

- A submitted manuscript is the version of the article upon submission and before peer-review. There can be important differences between the submitted version and the official published version of record. People interested in the research are advised to contact the author for the final version of the publication, or visit the DOI to the publisher's website.

- The final author version and the galley proof are versions of the publication after peer review.

- The final published version features the final layout of the paper including the volume, issue and page numbers.

Link to publication

\section{General rights}

Copyright and moral rights for the publications made accessible in the public portal are retained by the authors and/or other copyright owners and it is a condition of accessing publications that users recognise and abide by the legal requirements associated with these rights.

- Users may download and print one copy of any publication from the public portal for the purpose of private study or research.

- You may not further distribute the material or use it for any profit-making activity or commercial gain

- You may freely distribute the URL identifying the publication in the public portal.

If the publication is distributed under the terms of Article 25fa of the Dutch Copyright Act, indicated by the "Taverne" license above, please follow below link for the End User Agreement:

https://www.ou.nl/taverne-agreement

Take down policy

If you believe that this document breaches copyright please contact us at:

pure-support@ou.nl

providing details and we will investigate your claim.

Downloaded from https://research.ou.nl/ on date: 26 Apr. 2023 


\title{
What and how advanced medical students learn from reasoning through multiple cases
}

\author{
H. P. A. Boshuizen • M. W. J. van de Wiel $\bullet$ H. G. Schmidt
}

Abstract The study reported in this article concerns the questions what and how fourth-year medical students can learn from a series of cases that have a similar underlying problem. This question is crucial in the theoretical sense as it looks at mechanisms of updating and improving knowledge structures, which are conjectured to consist of 'illness scripts', which integrate knowledge about enabling conditions for a disease, the underlying fault, and the consequences or signs and symptoms of the disease. It was found that much learning was implicit, whilst students explicitly paid attention to variations in enabling conditions and consequences, which led to improvement of these knowledge components. Integration of biomedical knowledge into the fault component was, however, hampered by lack of knowledge and by misconceptions that students were unable to debug in the absence of learning resources or detailed feedback. The practical importance of this study stems from its close parallels to the learning situation in clinical practice, where patients (or cases) are the most important learning resources, whilst feedback on results is often minimal. Implications and possible solutions for clinical teaching are discussed.

Complementary access through this link http://rdcu.be/FwA9 